\title{
The Size of Flypaper Effect in Decentralizing Indonesia
}

\author{
Tengku Munawar Chali1 ${ }^{1}$ \\ Osaka University, Japan
}

\begin{abstract}
This study explores the flypaper effect in Indonesia using a spatial approach. Covering data from 2000-2014, the paper shows that grants stimulate overspending by local governments even though spatial interdependence is carefully treated. The elasticity of lump-sum grants to expenditure is stronger than the elasticity of matching grants. Further, elasticity of lump-sum grant is greater on routine expenditure, which shows the overdependency of local governments to lump-sum grant. The over - dependency phenomenon has not changed a lot even after a major changes of lump-sum grant formulation being applied by the 2004 decentralization law package.
\end{abstract}

Keywords: flypaper effect, intergovernmental transfer, local government expenditure.

\footnotetext{
${ }^{1}$ Tengku Munawar Chalil is a doctoral student at Department of Comparative Public Policy, Osaka School of International Public Policy (OSIPP), Osaka University, Osaka, Japan. E-mail:c-tengku@osipp.osaka-u.ac.jp
} 


\title{
The Size of Flypaper Effect in Decentralizing Indonesia
}

\author{
Tengku Munawar Chalil, Osaka University, Japan
}

\section{Introduction}

'The money seems to stick where it hits, like a flypaper' was a well-known remark by Arthur Okun that was cited in Inman (2008) where per-dollar nonmatching grants stimulate government expenditure more than the income of the citizens does. The exogenous federal grant to a local government recipient increases public expenditure more than an equivalent increase in citizens' income. Like a flypaper, the government grant stays in the hands of the government and the citizens' income stays in the citizens hand.

This study explores the flypaper effect in Indonesia. The flypaper effect is investigated by observing the marginal effect of federal grants to public expenditure and compare it with the marginal effect of household income. Using the case of decentralized Indonesia, the grant to local government is calculated by a central decision, which is independent to local government. This case would allow us to ensure that the grant is exogenous. ${ }^{1}$ This paper also specifies the spatial effect on estimating the size of the flypaper effect. Spatial effects matter to public expenditure. LeSage and Dominguez (2012) argue that a spillover of public goods creates bias of public expenditure in the sense that public service not only affects on the jurisdiction but also the nearest surrounding neighborhood/region. Furthermore, under open-bounded geography economic interaction among the surrounding neighboring regions should vary citizen income which causes omitted variables bias in conservative regression models. Therefore, spatial approach is necessary to determine the true magnitude of the flypaper effect, which is less-explored in previous literature on the subject.

An initial study to estimate the influence of flypaper effect was conducted by Gramlich et al. (1973) who estimates per-dollar addition of federal grant increases 43 cents of state government expenditure. Inman (2008) conducted a panel study of 41 city budgets and found a one-dollar increase of grant equivalently increase one-dollar of expenditure while companion income increased by 0.3 dollar. Other

\footnotetext{
${ }^{1}$ Indonesia has three-types of grants to local government, namely: general allocation grant, specific allocation grant, and revenue sharing. The first one has the closest characteristics to a lump-sum grant, the second is a matching grant, and the third is joint-ventures grant. General allocation grants accounted for the largest portion of total grants received by local government and it is purely calculated by a fixed formula as mandated on Law 33/2004 on fiscal transfer.
} 
studies have tried to revisit the concept of the flypaper effect. Conventional approach is to use the impact of the grant on total expenditure to observe the flypaper effect. Mattos, Rocha and Arvate (2011) argues that flypaper effect can be observed when a higher transfer from central government negatively affects the consumer's income based on the efficiency of taxation. Strumpf (1998) noted that flypaper effect is marked by higher overhead spending as an effect that is created by lump-sum welfare grants. Bailey and Connolly (1998) remarked on the future research areas for flypaper effect literature. They noted that federal grants should be exogenous from local government decisions in order to estimate the true magnitude of flypaper effect. Further, the future flypaper effect research should incorporate the economic of exit and voice, dynamics element and comprehensive multi-disciplinary model.

Kakamu, Yunoue and Kuramoto (2014) conducted a study exploring the spatial pattern of the flypaper effect. Using a combination of the Bayesian approach and a spatial model, they found that Local Allocation Tax (LAT) transfer causes a flypaper effect on education and land development spending in Japanese prefectures. Further spatial dependencies matter for the above-mentioned spending. This paper dives deeper into the analysis of municipal/city level. ${ }^{2}$ A spatial-maximum likelihood approach is employed to avoid overestimation of the flypaper effect. ${ }^{3}$ This paper also decomposed government expenditure into overhead and capital spending and shows that a per-unit grant stimulates more on overhead spending. In addition, grants are decomposed into three-types: lump-sum grant, matching grant, and revenue shares. ${ }^{4}$ Interestingly, the stimulation effect of a lump-sum grant less than revenue shares on total budget. The lump-sum grant significantly stimulates overhead spending but not capital spending. In contrast, a matching grant stimulates capital spending but significantly negatively affects routine spending. Revenue sharing has a moderate effect and citizen income has the lowest effect on all types of government expenditure. In all specifications, spatial error is not rejected as having an effect in correlating expenditure, grant and income.

Another issue that is explored in this paper is the matter of decentralization process in Indonesia towards fiscal illusion. Post the significant turbulence from centralization to decentralization in 1999, the relationship between central and

\footnotetext{
${ }^{2}$ Another honorable paper that needs to be mentioned is the study by Acosta (2010), in which he observed spatial the inter-dependency of the flypaper effect at county level at Buenos-Aires Province, Argentina.

${ }^{3}$ Megdal (1987) showed a Monte-Carlo evidence that using least-square estimation leads to erroneous conclusions regarding the flypaper effect. She also shows that coefficients that are produced by likelihood estimators have the closest value to true coefficient.

${ }^{4}$ Strumpf (1998) refers to that larger effect of grants on overhead spending as a flypaper effect. However, he did not include the types of grant into estimations.
} 
local government has shifted twice, at 2004 and $2014 .^{5}$ The shift significantly changed the characteristics of grant which describes the magnitude of the fly-paper effect over the two periods. In addition, the paper utilized geographically weighted regression as a tool to map the spatial pattern of the flypaper effect, which is not presented in previous studies.

The paper is structured as follows. Section 2 presents a model of the flypaper effect. Section 3 presents data description. Section 4 presents the spatial model on estimating the flypaper effect, including a general spatial nested model and geographically weighted regression. Section 5 discusses the empirical results and finally Section 6 concludes the study.

\section{Basic Model: Concept of Flypaper Effect}

The economic theory of an intergovernmental grant was explained by Bradford and Oates (1971) and Wyckoff (1990). If lump-sum grants are endowed to lower-tier governments, the per-capita share of lump-sum grants is equal to the increase of the median voter's income, in this sense lump-sum grants only create an income effect.

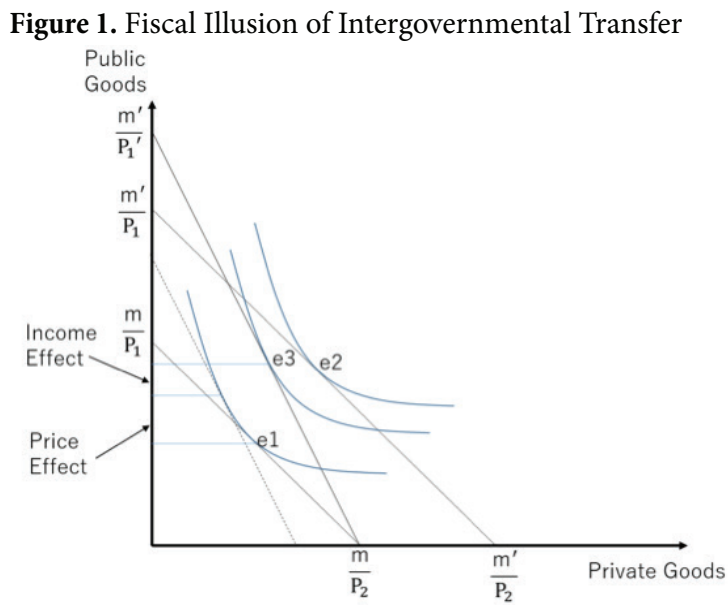

Figure 1 illustrates the lump-sum grant's income effect. In this illustration, assume that the bureaucrats follow median voter's preference. Before the grant is given, the median voter's optimal choice is 1 with the following budget constraint:

$$
m=P_{1} X_{1}+P_{2} X_{2}
$$

\footnotetext{
${ }^{5}$ There are three laws marking the milestone of decentralization policy in Indonesia. Law 22/1999 for pioneering decentralization, Law 32/2004 for rebalancing the power of central and local government, and Law 23/2014 as the final revision of decentralization policy. Since the recent law has not yet completed a derivative law package, this paper limits itself to dealing only with the pre- and post-Law 32/2004.
} 
Where $m$ is the median voter's income, $\mathrm{P}_{1}$ and $\mathrm{P}_{2}$ are the tax-price to local public goods' supply and price of private goods. $\mathrm{X}_{1}$ and $\mathrm{X}_{2}$ are the amount of public and private goods. Endowed with a share of a lump-sum grant from central government, the income effect shifts the income into $\mathrm{m}$ ' where the new local government expenditure is $e 2$. This is the condition only if bureaucrats follow the median voter's preference. However, the self-interested bureaucrats hide intergovernmental grants and perceive the tax-price of public goods, which is characterized as follows:

$$
\mathrm{P}^{1}{ }_{\mathrm{j}}=(\mathrm{G}-\mathrm{Z}) / \mathrm{G}
$$

Where $\mathrm{P}^{1}{ }_{\mathrm{j}}$ is the perceived tax price, $\mathrm{G}$ and $\mathrm{Z}$ are the real public spending and lump-sum transfer. Therefore, the median voter's preference for local government expenditure shift into $e 3$. The voters accept the condition since they receive higher provision of public goods but are not aware of the amount of grant received. As a result, a lump-sum grant from central government stays with local government, which is known as the flypaper effect.

Several model specifications are employed to estimate the flypaper effect (see: Kakamu, Yunoue and Kuramoto, 2014; Gramlich et al., 1973; Strumpf, 1998; and Worthington and Dollery, 1999). The use of either linear or log - linear regression are acceptable. The linear reduced form on estimating the flypaper effect is expressed as follows:

$$
G_{i}=\alpha+\beta_{1} z_{i}+\beta_{2} m_{i}+\varepsilon_{i}
$$

Where $G_{i}$ is public expenditure by municipal/city government $i, z_{i}$ is the transfer from central government, and $m_{i}$ is household income in the municipal/ city $i$ jurisdiction area. $\varepsilon_{i}$ is the error term. Inman (2008) mentioned that if political representatives follow the citizens preference as follows:

$$
\frac{d G / d z}{d G / d z}=\frac{\beta_{1}}{\beta_{2}} \leq 1
$$

in most case, otherwise we can expect the existence of the flypaper effect.

\section{Data}

The dataset from the Indonesia Database for Economic Research (INDO-DAPOER) - The World Bank is utilized in this study. The data covers period 2000-2014 at municipal/city level but unbalance by several restraints. Variables that are employed and their summary statistics are described in Table 1. The estimation employs several control variables such as regional GDP and shares of origin revenue as treatment for fiscal disparity bias at observation. The regional and provincial dummy variables are utilized to treat heterogeneities of 
local government characteristic's bias such as language, culture, and customs.

Table 1. Statistics Summary

\begin{tabular}{|c|c|c|c|c|}
\hline Variable & Mean & Pre-Desent & Post-Desent & Difference- \\
\hline 2000-2014 & $2000-2004$ & $2005-2014$ & in-Mean & \\
\hline \multirow[t]{2}{*}{ Household Income } & 172.22 & 93.43 & 222.31 & -156.64 \\
\hline & & & & $(-14.89)$ \\
\hline \multirow[t]{2}{*}{ Total Spending } & 533.76 & 254.15 & 661.46 & -438.78 \\
\hline & & & & $(-35.19)$ \\
\hline \multirow[t]{2}{*}{ Capital Spending } & 146.59 & 50.96 & 180.63 & -133.87 \\
\hline & & & & $(-12.90)$ \\
\hline \multirow[t]{2}{*}{ Overhead Spending } & 282.49 & 128.98 & 346.78 & -240.93 \\
\hline & & & & $(-35.33)$ \\
\hline \multirow[t]{2}{*}{ Total Grant } & 450.49 & 203.66 & 499.26 & -314.13 \\
\hline & & & & $(-41.39)$ \\
\hline \multirow[t]{2}{*}{ Equalization Grant } & 317.49 & 149.82 & 391.87 & -255.55 \\
\hline & & & & $(-40.58)$ \\
\hline \multirow[t]{2}{*}{ Specific Allocation Grant } & 33.24 & 9.28 & 42.83 & -33.40 \\
\hline & & & & $(-38.77)$ \\
\hline \multirow[t]{2}{*}{ Revenue Sharing } & 50.48 & 23.43 & 64.56 & -47.70 \\
\hline & & & & $(-6.11)$ \\
\hline
\end{tabular}

Notes: All variable values in Billion Rupiah; Student t-test values in brackets.

\section{Spatial Model for Flypaper Effect}

The general form for the spatial linear model is expressed as follows:

$$
\begin{gathered}
Y=\sigma W Y+\alpha I_{N}+X \beta+W X \theta+\mu \\
\mu=\lambda W \mu+\varepsilon
\end{gathered}
$$

The above equation is also known as general nesting spatial model (Elhorst, 2014), where $W$ is non-negative spatial contiguity matrix, $\sigma$ is the coefficient of spatial auto-regressive, $\lambda$ is the coefficient of spatial auto-correlation, and $\beta$ and $\theta$ are unknown parameters to be estimated. Modifying equation (1), the empirical equation of the flypaper effect is written as follows:

$$
\begin{gathered}
G_{i}=\sigma W G_{i}+\alpha I_{N}+\beta_{1} Z_{i}+\beta_{2} m_{i}+\beta_{k} X_{i}+\theta W X_{i}+\mu \\
\mu=\lambda W \mu+\varepsilon
\end{gathered}
$$

\subsection{Building the Spatial Weighting Matrix}

The spatial weighting matrix is a non-negative matrix $\mathrm{W}=(w i j: i, j=1, \ldots$, $n$ ) that summarizes spatial relations between $\mathrm{n}$ spatial units. In practice, weighting is categorized by distance, boundaries, and mix-distance and boundaries. In this paper, 
weighting based on boundaries is selected in particular the queen's contiguity matrix. If a unit $i$ shares a single boundary unit then it is considered as neighborhood, which is defined by:

$$
W_{i j}= \begin{cases}1, & \text { bnd }(i) \cap \operatorname{bnd}(j) \neq \emptyset \\ 0, & \text { bnd }(i) \cap \operatorname{bnd}(j)=0\end{cases}
$$

To remove the dependence of extraneous scale factors, $W_{i j}$ needs to be normalized with a sum equal to one, i.e.,

$$
\sum_{i=1}^{N} w_{i j}=1
$$

Since the queen's contiguity matrix contains binary values, its creation process is row-normalized with the sum to one. The creation of the weighting matrix using Indonesian data, GeoDa (Anselin, Syabri and Kho, 2006) is utilized. The archipelagic condition of Indonesia has resulted in 24 observations that are neighborless since it is surrounded by sea (none share a single boundary with neighborhood).

\subsection{Spatial Lag Model (SLM)}

From a general nesting spatial model, when dependent variables are assumed to be exogenous i.e., $\theta=0$ and homogeneity is assured i.e., $\lambda=0$ then the model can be expressed as follows:

$$
\mathrm{Y}=\sigma \mathrm{WY}+\alpha \mathrm{I}_{\mathrm{N}}+\mathrm{X} \beta+\mu
$$

This model is known as spatial lag model. The approach on estimating this type of model is to use maximum likelihood estimation ((Anselin and Bera, 1998) and (Anselin, Syabri and Kho, 2006)).

\subsection{Spatial Error Model (SEM)}

Spatial Error Model specifies the spatial influences in residual terms and is exogenous of independent variables. The model is expressed as follows:

$$
\begin{gathered}
\mathrm{Y}=\alpha \mathrm{I}_{\mathrm{N}}+\mathrm{X} \beta+\mu \\
\mu=\lambda \mathrm{W} \mu+\varepsilon \\
\text { or } \\
\mathrm{Y}=\alpha \mathrm{IN}+\mathrm{X} \beta+(\mathrm{I}-\lambda \mathrm{W})^{-1} \varepsilon
\end{gathered}
$$

Similar to spatial lag model, spatial error model is also estimated using maximum likelihood estimation. 


\subsection{Geographically Weighted Regression (GWR)}

Geographical weighted regression enables local variation in each observation. The weighting matrix of GWR contains geographical weights on diagonal elements and zero for off-diagonal. For $\mathrm{u}_{\mathrm{i}}$ and $\mathrm{v}_{\mathrm{i}}$ as Geographic XY-Coordinate, then:

$$
\mathrm{W}\left(u_{i}, v_{j}\right)=\left[\begin{array}{ccc}
w_{1}\left(u_{i}, v_{j}\right) & 0 & 0 \\
0 & \ldots & 0 \\
0 & 0 & w_{N}\left(u_{i}, v_{j}\right)
\end{array}\right]
$$

The weight $\mathrm{w}_{\mathrm{i}}\left(\mathrm{u}_{\mathrm{i}}, \mathrm{v}_{\mathrm{i}}\right)$ assigned to each observation is based on a decay function that is measured from the centroid of observation $i$ 's (Lewandowska-Gwarda, 2018). The decay function utilized in this research is the fixed kernel decay function.

After obtaining the weighting matrix, then the general model of GWR is written as follows:

$$
\mathrm{y}_{\mathrm{i}}=\alpha\left(\mathrm{u}_{\mathrm{i}}, \mathrm{v}_{\mathrm{j}}\right)+\sum \beta_{\mathrm{k}}\left(\mathrm{u}_{\mathrm{i}}, \mathrm{v}_{\mathrm{j}}\right) \mathrm{x}_{\mathrm{ik}}+\varepsilon
$$

The estimated coefficient is expressed by:

$$
\beta=\left[X^{T} W\left(u_{i}, v_{i}\right) X\right]^{-1} X^{T} W\left(u_{i}, v_{i}\right) Y
$$

GWR is useful to illustrate the spatial distribution of the flypaper effect while also accounting for spillover bias. The ArcGIS 10.2 software is utilized to run GWS.

\section{Results and Discussion}

\subsection{Size of Flypaper Effect in Indonesia}

Evidence of the flypaper effect is presented in Table 2. The reduced form in equation 1 is estimated using three models; ordinary least square (OLS), Spatial Lag Model (SLM), and Spatial Error Model (SEM). Results suggest that one-percent increase of grant stimulates 0.75 percent changes of total government expenditure. In the other hand, one-percent increase of total household income stimulates 0.11 percent changes of government expenditure. The flypaper effect $\left(\beta_{1} \beta_{2}\right)$ is around 6.9 if Spatial Error Model was chosen. Comparing which model is efficient, all model present a similar result of standard errors. However in a goodness-to-fit sense, the spatial error model is superior, with the largest log-likelihood value. OLS as expected, has estimation bias since the Breush-Pagan test and Jarque-Bera statistics show rejection of null hypothesis that homogeneity on residual and normally distributed error. Moran's I statistic varies from 0 to 1 , showing the existence of spatial distribution of the independent variable. Null means spatial distribution is random and one means spatial distribution is systematic. The Moran's I statistic for spatial correlation is greater than zero $(0.46)$, indicating there is spatial interdependency of 
total expenditure. The Moran's I error in table 2 column (1) also not zero, indicating the presence of spatial heterogeneities. The Moran plot in Figure 2 shows a correlation of neighbor observation with initial observation.

Table 2. Estimates of "flypaper effect"

Dep.Var Total Spending

OLS

(1)

$\begin{array}{ll}\text { Grant } & 0.59 \\ & (0.06) \\ \text { HH Income } & 0.22 \\ & (0.05) \\ \text { GDRP } & 0.27 \\ & (0.04) \\ \text { Tax Share } & -0.09 \\ & (0.19)\end{array}$

W. Total

Spending

Lambda

Province

Dummy

Regional

Dummy

Constant

0.10

(0.08)

Log. Likeli-

hood

Jarque-Bera

p-value

Breush-Pagan

Test

p-value

0.00

Moran's I

0.29

p-value

0.00

LR Spatial

Test

Flypaper Size $\quad 2.6$

$\mathrm{N}$

431.00
Spatial Lag

(2)

0.64

(0.06)

0.19

(0.05)

0.25

(0.04)

0.04

(0.18)

0.15

(0.03)

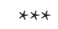

0.75

(0.06)

0.11

(0.05)

0.21

(0.04)

0.12

(0.19)

0.08

(0.05)

0.34

(0.05)

Yes

Yes

0.14

(0.08)

(0.09)

162.22

169.02

376.43

762.42

0.00

0.00

18.43

16.00

3.2

6.9

431.00
Spatial Error

(3)

Notes: All variables are standardized into logarithmic form, treated in percapita form and deflated using year 2000 as constant year. Standard errors in brackets; *** denotes significance at $1 \%$ level, **at $5 \%$ and $*$ at $10 \%$ 
Figure 2. Moran's I plot of lag-total expenditure

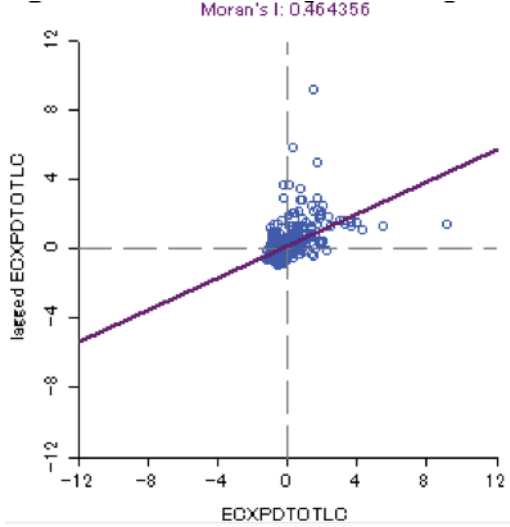

For the spatial lag model in Table 2, which is referred to in Equation 2, the coefficient of W.Total Spending $(\sigma)$ is positive and significant, which indicates spatial auto-regressive matters. After execution of the spatial auto-regressive model, the residuals are plotted in Figure 3. The plot shows the correlation of spatial lag error and observation error, which indicates a spatial dependency problem located in both autoregressive and omitted variable. Looking at the spatial error model, which is referred to in Equation 3, $\lambda$ is significant at $1 \%$ level, which indicates that spatial autocorrelation matters. Therefore, utilizing spatial auto-regressive variables and treating spatial heterogeneity, we can obtain a better estimator. In summary, the spatial error model is superior to other employed estimators, where residual errors are homogeneous as presented in Figure 4. In addition, low $p$-value of Likelihood Ratio (LR) spatial test indicates strong relevance of spatial dependency on residuals (Anselin, Syabri and Kho, 2006).

Figure 3. Moran's I plot of error by

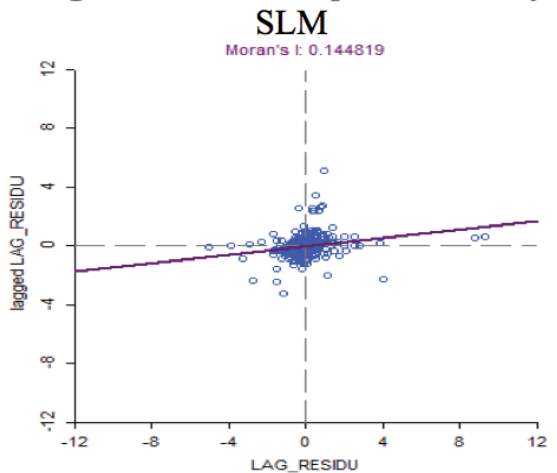

Figure 4. Moran's I plot of error by

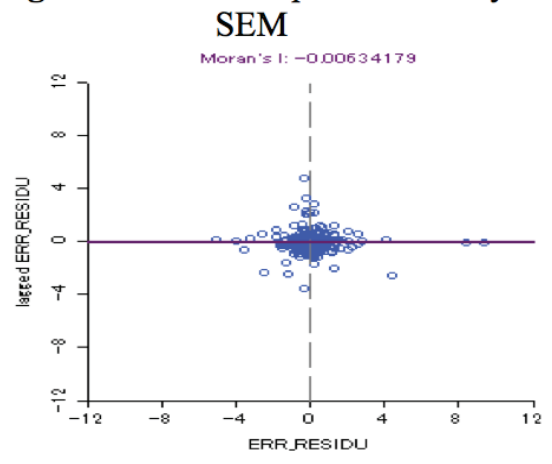

The stimulation effect of grants in Indonesia as estimated in this paper is 0.75, in comparison with Italy;1.47 (Gennari and Messina, 2014), Argentina;0.66 
(Acosta, 2010), The United States;0.43 (Gramlich et al., 1973), and India;1.64 (Lalvani, 2002). The mentioned papers show that grants stimulate government spending more than an increase of income of median voters. A contrasting finding is reported by Worthington and Dollery (1999), where in Australian local government, grants are negatively related to spending. However they admitted mis-specification problems and the omitted problem bias in their research.

Table 3. Flypaper Effect by Expenditure Objective

\begin{tabular}{|c|c|c|c|c|c|c|c|c|c|c|c|c|}
\hline \multirow{4}{*}{$\begin{array}{l}\text { Dep.Var } \\
\text { Grant }\end{array}$} & \multicolumn{6}{|c|}{ Routine Spending } & \multicolumn{6}{|c|}{ Capital Spending } \\
\hline & \multirow{2}{*}{\multicolumn{2}{|c|}{$\begin{array}{l}\text { OLS } \\
(1)\end{array}$}} & \multirow{2}{*}{\multicolumn{2}{|c|}{$\begin{array}{c}\text { Spatial Lag } \\
\text { (2) }\end{array}$}} & \multirow{2}{*}{\multicolumn{2}{|c|}{$\begin{array}{c}\text { Spatial Error } \\
\text { (3) }\end{array}$}} & \multirow{2}{*}{\multicolumn{2}{|c|}{$\begin{array}{l}\text { OLS } \\
(4)\end{array}$}} & \multirow{2}{*}{\multicolumn{2}{|c|}{$\begin{array}{c}\text { Spatial Lag } \\
(5)\end{array}$}} & \multirow{2}{*}{\multicolumn{2}{|c|}{$\begin{array}{c}\text { Spatial Error } \\
(6)\end{array}$}} \\
\hline & & & & & & & & & & & & \\
\hline & 0.70 & $* * *$ & 0.73 & $* * *$ & 0.78 & $* * *$ & 0.33 & $* * *$ & 0.43 & $* * *$ & 0.53 & $* * *$ \\
\hline & $(0.05)$ & & $(0.04)$ & & $(0.04)$ & & $(0.06)$ & & $(0.06)$ & & $(0.06)$ & \\
\hline \multirow[t]{2}{*}{ HH Income } & 0.16 & $* * *$ & 0.15 & $* * *$ & 0.11 & $* * *$ & 0.40 & $* * *$ & 0.33 & $* * *$ & 0.28 & $* * *$ \\
\hline & $(0.04)$ & & $(0.04)$ & & $(0.04)$ & & $(0.05)$ & & $(0.05)$ & & $(0.05)$ & \\
\hline \multirow[t]{2}{*}{$\begin{array}{l}\text { GDRP per } \\
\text { capita }\end{array}$} & 0.18 & $* * *$ & 0.18 & $* * *$ & 0.12 & $* * *$ & 0.26 & $* * *$ & 0.23 & $* * *$ & 0.18 & $* * *$ \\
\hline & $(0.03)$ & & $(0.03)$ & & $(0.03)$ & & $(0.04)$ & & $(0.04)$ & & $(0.04)$ & \\
\hline \multirow[t]{2}{*}{ Tax Share } & -0.10 & & -0.02 & & 0.16 & & -0.20 & & 0.02 & & 0.16 & \\
\hline & $(0.14)$ & & $(0.14)$ & & $(0.14)$ & & $(0.20)$ & & $(0.18)$ & & $(0.19)$ & \\
\hline \multirow{2}{*}{$\begin{array}{l}\text { W. Routine } \\
\text { Spending }\end{array}$} & & 0.10 & $* * *$ & 0.12 & $* * *$ & & & & & & & \\
\hline & & & $(0.03)$ & & $(0.05)$ & & & & & & & \\
\hline \multirow{2}{*}{$\begin{array}{l}\text { W. Capital } \\
\text { Spending }\end{array}$} & & & & & & & & 0.27 & $* * *$ & 0.18 & $* * *$ & \\
\hline & & & & & & & & & $(0.04)$ & & $(0.06)$ & \\
\hline \multirow[t]{2}{*}{ Lambda } & & & & & 0.43 & $* * *$ & & & & & 0.40 & $* * *$ \\
\hline & & & & & $(0.05)$ & & & & & & $(0.05)$ & \\
\hline $\begin{array}{l}\text { Province } \\
\text { Dummy }\end{array}$ & Yes & & Yes & & Yes & & Yes & & Yes & & Yes & \\
\hline $\begin{array}{l}\text { Regional } \\
\text { Dummy }\end{array}$ & Yes & & Yes & & Yes & & Yes & & Yes & & Yes & \\
\hline \multirow[t]{2}{*}{ Constant } & -0.27 & $* * *$ & -0.24 & $* * *$ & -0.27 & $* * *$ & -0.46 & $* * *$ & -0.33 & $* * *$ & -0.35 & $* * *$ \\
\hline & $(0.06)$ & & $(0.06)$ & & $(0.07)$ & & $(0.08)$ & & $(0.04)$ & & $(0.10)$ & \\
\hline $\begin{array}{l}\text { Log. Likeli- } \\
\text { hood }\end{array}$ & 262.30 & & 266.88 & & 292.01 & & 128.21 & & 152.72 & & 167.28 & \\
\hline Jarque-Bera & 778.70 & & & & & & 280.25 & & & & & \\
\hline p-value & 0.00 & & & & & & 0.00 & & & & & \\
\hline $\begin{array}{l}\text { Breush-Pagan } \\
\text { Test }\end{array}$ & 436.30 & & 427.12 & & 714.88 & & 213.15 & & 221.28 & & 370.00 & \\
\hline $\mathrm{p}$-value & 0.00 & & 0.00 & & 0.00 & & 0.00 & & 0.00 & & 0.00 & \\
\hline Moran's I & 0.31 & & & & & & 0.32 & & & & & \\
\hline $\mathrm{p}$-value & 0.00 & & & & & & & & & & & \\
\hline LR Spatial Test & & & 9.15 & & 62.87 & & & & 49.01 & & 45.47 & \\
\hline $\mathrm{N}$ & 431.00 & & 431.00 & & 407.00 & & 418.00 & & 418.00 & & 418.00 & \\
\hline Flypaper & 4.34 & & 5.02 & & 7.41 & & 0.83 & & 1.31 & & 1.91 & \\
\hline
\end{tabular}

Notes: All variables are standardized into logarithmic form, treated in percapita form and deflated using year 2000 as constant year. Standard errors in brackets; *** denotes significance at $1 \%$ level, **at $5 \%$ and $*$ at $10 \%$. 
In addition, Table 3 reports the size of flypaper when total spending is decomposed into capital spending and routine spending. Strumpf (1998) notes that the flypaper effect can be observed when the elasticity of grant on overhead spending greater than the elasticity of income. The flypaper effect still exist in overhead spending, but the size is not as large as that of total grants (Table 2). Interestingly, flypaper effect size is smaller in capital spending. It should be noted that the elasticity of grant to capital spending is relatively smaller than the elasticity of grant to overhead spending.

One explanation in this case is fiscal illusion. This theory elucidates that government deceives the median voters by increase the public budget, but in most cases spend the budget according to their preference, which weights on routine spending i.e., paying salaries, meetings, official business trips, and others, compared to capital spending i.e., increasing assets, building infrastructure, and investing in physical treasury. The results provide empirical evidence where grants stimulate routine spending more than physical spending.

Table 4 presents the detail regression on table 3, particularly when the total grant is disaggregated into equalization grants (lump-sum grants), specific allocation grants, and revenue sharing. The table only presents estimation using spatial error model. The size of elasticity of income to total grant becomes not significant. The coefficients of lump sum grants and revenue sharing are significantly massive to boost the total expenditure. The lump sum grants effect becomes more substantial for routine expenditure. In contrast, the specific allocation grants, which usually marked to physical spending, is significant to capital expenditure than the lump sum grants. The income of voters also has significant effect to capital spending, which was the spending that voters value the most. As predicted by Bradford and Oates (1971), the effect of a lump-sum grant is largest on stimulating routine spending where the lump sum grants shift the income of the disburse parties. In contrast with a specific allocation grant (matching grant), it has a small effect on routine spending but large to capital spending. The matching grants creates a substitution effect, which lower the price of public goods than private goods. As a consequence, increasing the supply of public service. Revenue sharing has a moderate effect but the impact direction is similar to the lump-sum grant. In Indonesia, the nature of revenue sharing is a mixed with lump sum grants and matching grants. For example, revenue shares from natural resources such as mineral has effect as the lump sum grants but revenue shares from land and income tax should has effect as the matching grants. Further investigation in this issue should be taken as note in the future research. 
Table 4.Flypaper Effect by Expenditure Objective and nature of grants

Dep. Var

Total Expenditure

(1)

Equalization Grants

Specific Allocation Grants

HH Income

GDRP per capita

Tax Share

W.Total Expenditure

W.Routine Expenditure

W.Capital Expenditure

Lambda

Province Dummy

Regional Dummy

Constant

Log. Likelihood

LR Spatial Test

$\mathrm{N}$
0.46

0.04

0.08

0.03

0.43

0.02

0.01

0.03

$-0.01$

0.02

0.27

0.11

$-0.02$

0.03

$\begin{array}{ll}-0.09 & * * * \\ & 0.04\end{array}$

Routine Expenditure

(2)

(3)

$\begin{array}{lll}0.62 & * * * & 0.12 \\ 0.05 & & 0.04 \\ 0.09 & * * * & 0.24 \\ 0.04 & & 0.03 \\ 0.20 & * * * & 0.43 \\ 0.02 & & 0.02 \\ 0.04 & & 0.15 \\ 0.03 & & 0.03 \\ 0.04 & & 0.00 \\ 0.03 & & 0.02 \\ 0.18 & & 0.37 \\ 0.13 & & 0.11\end{array}$

Capital Expenditure

$\begin{array}{lll} & 0.07 & * * \\ & & 0.04 \\ 0.33 & * * * & 0.28 \\ 0.05 & & 0.05 \\ \text { Yes } & & \text { Yes } \\ \text { Yes } & & \text { Yes } \\ 0.10 & * * * & 0.42 \\ 0.08 & & 0.07 \\ 343.31 & & 382.44 \\ 36.14 & & 24.92 \\ 404.00 & & 404.00\end{array}$

Notes: Spatial Error Model is utilized. All variables are standardized into logarithmic form, treated in percapita form and deflated using year 2000 as constant year. Standard errors in brackets; *** denotes significance at 1\% level, $* *$ at $5 \%$ and $*$ at $10 \%$.

Figure 5 presents the distribution of the flypaper effect using GWR. The modified version of equation 1 is used as the basic econometric model. GWR produces a local estimated coefficient for each observation. The size of the flypaper effect on municipal $i$ is expressed as $\beta_{1}\left(u_{i}, u_{j}\right) / \beta 2\left(u_{i}, u_{j}\right)$, which are plotted on Figure 5 . The darker color indicates the larger size of the flypaper effect. As illustrated, distribution of the flypaper effect is almost similar with the distribution of dependency of local government on intergovernmental grants..The flypaper effect size in the southern part of Indonesia, especially Java island, is relatively small compared with the other islands. Indonesian economic activity is concentrated in Java island, which indicates a high household income. The grant effect is not as large as other parts of Indonesia, for example southern Sumatra, Papua, Sulawesi, and western Kalimantan. 
Figure 5. Spatial Distribution of Flypaper Effect using GWS

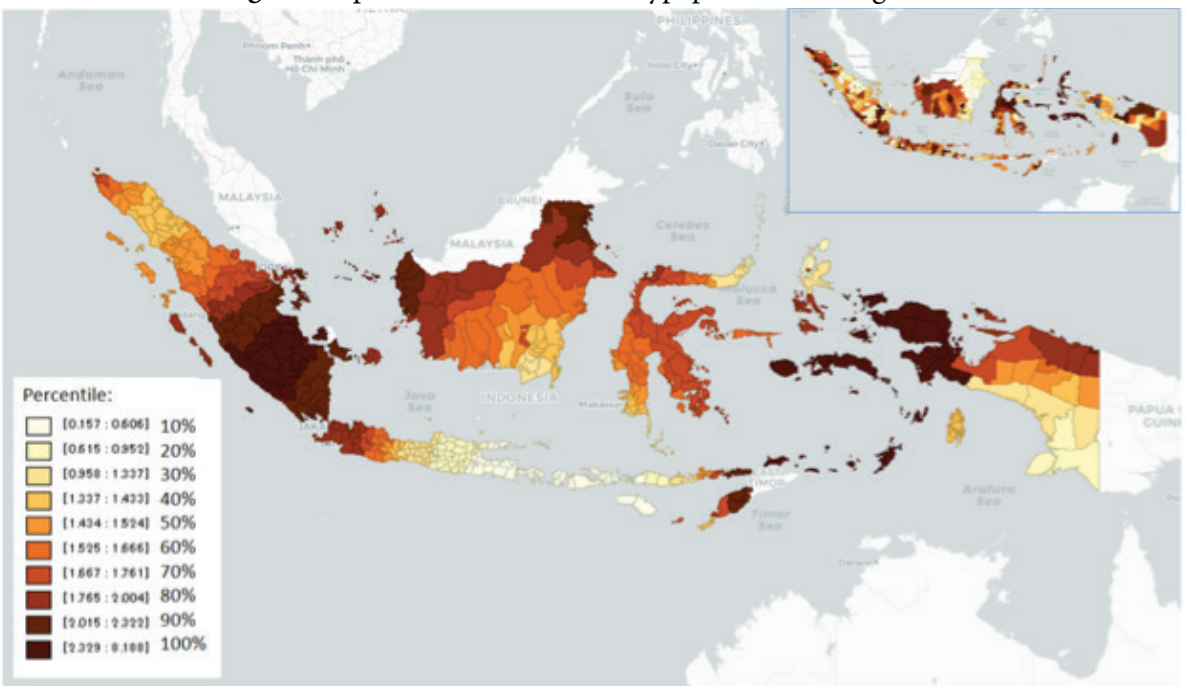

Inset: Spatial Distribution of Grants Dependency

Stats: Bandwidth: 4.07 AIC: 4,789 Sigma: 60.96

\subsection{Pre- and Post- implementation of a Balance Decentralization}

Significant changes of decentralization policy after year 2004, when the central government rebalanced the power by strengthening the role of sub-national government to coordinate development in the local regions and reformulating the calculation of grants.In Table 5, part A, the flypaper effect is measured during pre-2004 period and post-2004 period. Here, the spatial error model is utilized. The stimulation effects of grants increases by 0.05 points after rebalancing decentralization. The stimulation effects also excalate for both in capital and routine spending. The plausible explanation behind this result is that the grant is significantly boosted post-2004, which stimulates the self-interest local government's boost in overhead spending.

Figure 6 Spatial Distribution of Flypaper Effect before 2004 using GWR

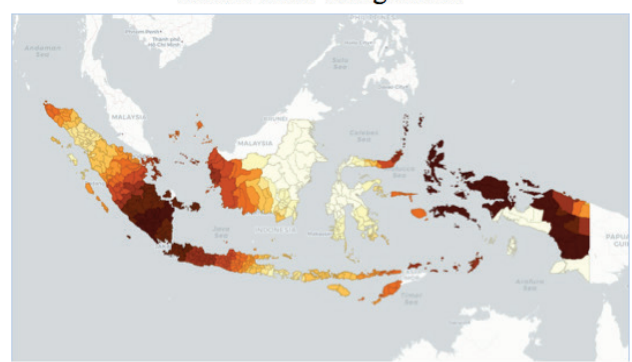

Stats: Bandwidth: 4.07 AIC: 4,147 Sigma: 28.97
Figure 7 Spatial Distribution of Flypaper Effect after 2004 using GWR

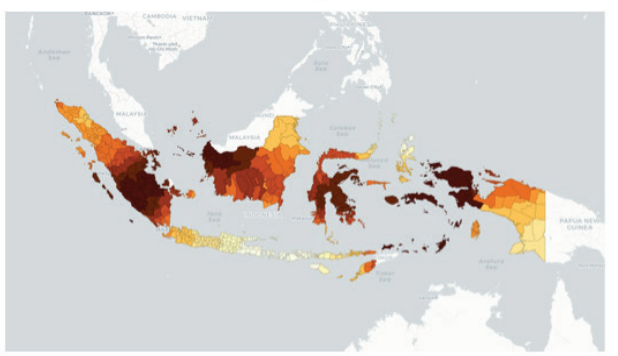

Stats: Bandwidth: 4.07 AIC: 5,085 Sigma: 85.93 
Table 5. Flypaper Effect by Dynamic of Decentralization

Dep.Var

Total Spend

Pre-

(1)

Post- Pre- Post-

(2)

Capital Spend

(3) (4)

Pre-

Post-

Part A:

Grant

HH Income

$0.85 \quad * * * \quad 0$.

(0.02)

(0.02)

$(0.05)$

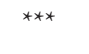

0.56
$(0.02)$

$* * *$

(5)

(6)

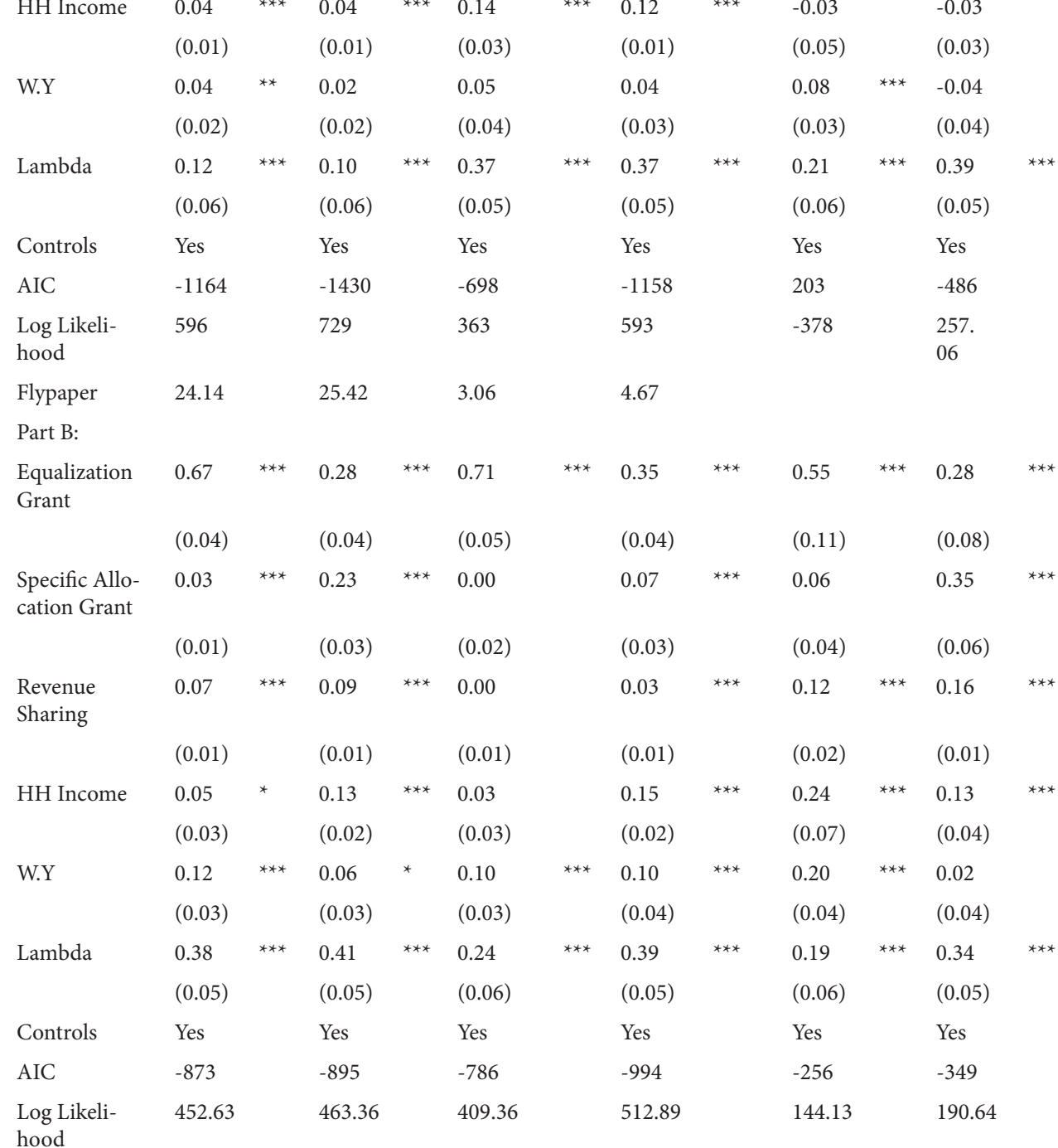

Notes: Spatial Error Model is utilized. All variables are standardized into logarithmic form, treated in percapita form and deflated using year 2000 as constant year. Control variables are PeCapita GDRP, Tax share, provincial and regional dummies. Standard errors in brackets; *** denotes significance at $1 \%$ level, **at $5 \%$ and * at $10 \%$.

However, the issue of multi-collinearity needs to be addressed, since there should be a possible correlation between grant and household income, directly or indirectly. As seen in the illustration, several portions of grant transferred is used by local government to be spent on households i.e. tax rebates, household grants, 
or family incentives, and in this case a higher grant stimulates higher income.

Table 5, part B presents the effect of disaggregated grants to government expenditure. The effect of household income on government expenditure is substantially greater after 2004 while the effect of specified intergovernmental grants is lower after 2004. The equalization grant effect is significantly lowered by 0.39 points for total spending even though the amount is greater after 2004 . The change of equalization grant with the inclusion of local government basic allocation (local's salary and others) limits the local bureaucrats to freely spending the equalization grant. Before 2004, local governments could freely spend the equalization grant for example not only paying salaries but also allowances or bonuses to their employees. After the change, salaries and allowances were locked by central government, which resulted in the equalization grant only financing public service authorities. This reasoning also explains why the effect of equalization grant decreases on overhead spending after 2004. The effect of the specific allocation grant changes a lot after 2004 where the central government are increasing the amount of matching grants and proliferation of matching grants target. The recent policy also target the fulfilment of Minimum Standard of Service (MSS) by utilizing funding from specific allocation grants. Study by Roudo and Chalil (2016) shows the significant impact of the specific allocation grants for achieving national target. The effect of revenue sharing remains similar to the equalization grant.

Using GWR, the changes of size and spatial distribution of the flypaper effect is checked. Figure 6 shows flypaper distribution before 2004. The size of the flypaper effect is larger in eastern parts of Indonesia and the southern parts of Sumatra island. Sulawesi and the western part of Kalimantan have a smaller size of flypaper effect compared to other parts of Indonesia. Figure 7 shows the changes after 2004. The distribution is similar to that in Figure 5. Central Maluku island has the highest magnitude of the flypaper effect with a value of 11.7 and the lowest is Surabaya city with a value of 0.11 . After decentralization, the eastern part of Kalimantan became dependent on grants where the size of the flypaper effect became greater after 2004. Java island, which acts as the centre of development, experienced a shrinking in the size of the flypaper effect after the policy changes.

\section{Concluding Remark}

After almost five decades of study on the effect of intergovernmental grants, the flypaper effect remains unavoidable when a lump-sum transfer granted to local bureaucrats. The grant from government stays in the government while citizens' 
income remains with the citizens.

This paper explores the flypaper effect in Indonesia using the spatial approach. The spatial approach is offered in this paper due to the fact that ignoring the issues of spillover of public expenditure, the mobility of the median voters, and inter-regional relationships would create bias when estimating size of flypaper effect. In short, spatial dependency is important in estimating the flypaper effect. This study employs various techniques and experiments controlling the spatial effect on measuring the size of the flypaper effect, which has a value of 6.9, using Indonesian data.

Further, this paper presents the natural effect of grant by its type. It shows evidence on intergovernmental grants theory (See: Bradford and Oates, 1971; Courant, Gramlich and Rubinfeld, 1978; and Romer and Rosenthal, 1980) where the impact of a lump-sum grant and matching grant are different, whether on aggregate spending, overhead spending or capital spending.

This paper also offers an analysis of the dynamics of the flypaper effect due to the decentralization process, particularly in the case of Indonesia, where the size of the flypaper effect became smaller. Finally, spatial distribution of the flypaper effect in Indonesia is presented that emphasizes spatial matter for creating an asymmetric flypaper effect.

However, one thing that needs to be noted is that household income is not independent from grants, which suggests that endogeneity needs to be carefully addressed. Instrumental analysis should be useful but finding a perfect instrument to control the endogeneity is an enormous challenge for future research. Furthermore, household income is not a perfect variable to represent the income of median voters, which criticizes conventional reduced form estimation of flypaper effect.

For Indonesian policymaking, several policy issues need to be addressed. The first is rethinking the equalization grant design. The equalization grant is indeed necessary as mandated in decentralization but it stimulates nonimportant overhead spending rather than the capital spending necessary for citizens. The government homework must be to find how to make citizens aware of grants and to monitor how well the bureaucrats use them. Second, the spatial distribution of flypaper is not equal across regions, showing which local governments rely on grants and which government are not dependent on grants. By mapping the spatial distribution, central government can address which areas need to be evaluated in terms of grant and expenditure management. Finally, the decentralization process in Indonesia must be assessed, while questioning 
whether it has hit a development milestone and is creating better public services.

\section{References}

Acosta, P. (2010). The flypaper effect in presence of spatial interdependence: evidence from Argentinean municipalities. The annals of regional science, 44(3): 453-466.

Anselin, L., Bera, A.K. (1998). Spatial dependence in linear regression models with an introduction to spatial econometrics. Statistics Textbooks and Monographs, 155: 237-290.

Anselin, L., Syabri, I., \& Kho, Y. (2006). GeoDa: an introduction to spatial data analysis. Geographical analysis, 38(1): 5-22.

Bailey, S.J., Connolly, S. (1998). The flypaper effect: Identifying areas for further research. Public choice, 95(3-4): 335-361.

Bradford, D.F., Oates. W.E. (1971). "Towards a predictive theory of intergovernmental grants." The American Economic Review, 61(2): 440-448.

Courant, P.N, Gramlich, E.M, \& Rubinfeld, D.L. (1978). The stimulative effects of intergovernmental grants: Or why money sticks where it hits. University of Michigan, Institute of Public Policy Studies.

Elhorst, J.P. (2014). Linear spatial dependence models for cross-section data. In Spatial Econometrics. 5-36. Springer.

Gennari, E, and Messina, G. (2014). How sticky are local expenditures in Italy? Assessing the relevance of the flypaper effect through municipal data. International tax and public finance, 21(2): 324-344.

Gramlich, E. M, Galper. H, Goldfeld, S., \& McGuire, M. (1973). State and local fiscal behavior and federal grant policy. Brookings Papers on Economic Activity, 1973(1): 15-65.

Hamid, E. S. (2003). Formula Alternatif Dana Alokasi Umum. Journal of Indonesian Economy and Business, 18(3).

Inman, R. P. (2008). The flypaper effect. National Bureau of Economic Research. Kakamu, K., Yunoue, H., \& Kuramoto, T. (2014). Spatial patterns of flypaper effects for local expenditure by policy objective in Japan: A Bayesian approach. Economic Modelling, 37: 500-506.

Lalvani, M. (2002). The flypaper effect: evidence from India. Public Budgeting \& Finance, 22(3): 67-88.

LeSage, J.P., Dominguez, M. (2012). The importance of modeling spatial spillovers in public choice analysis. Public Choice, 150(3- 4): 525-545.

Lewandowska-Gwarda, K. (2018). Geographically Weighted Regression in the Analysis of Unemployment in Poland. ISPRS International Journal of Geo-Information, 7(1): 17.

Mattos, E., Rocha, F., Arvate, P. (2011). Flypaper effect revisited: evidence for tax collection efficiency in Brazilian municipalities. Estudos Economicos 
(Sao Paulo), 41(2): 239-267.

Megdal, S. B. (1987). The flypaper effect revisited: An econometric explanation. The Review of Economics and Statistics, 347-351.

Romer, T., Rosenthal, H. (1980). An institutional theory of the effect of intergovernmental grants. National Tax Journal, 451-458.

Roudo, M., \& Chalil, T. M. (2016). Depolarization in Delivering Public Services? Impacts of Minimum Service Standards (MSS) on the Quality of Health Services in Indonesia. Journal of Regional and City Planning. https:// doi.org/10.5614/jrcp.2016.27.1.1

Strumpf, K.S. (1998). A predictive index for the flypaper effect. Journal of Public Economics, 69(3): 389-412.

Worthington, A.C., Dollery, B.E. (1999). Fiscal illusion and the Australian local government grants process: How sticky is the flypaper effect? Public Choice, 99(1-2): 1-13.

Wyckoff, P. G. (1990). The simple analytics of slack-maximizing bureaucracy. Public Choice, 67(1): 35-47. 